$270 g$

A Concordance to the Poems of

W. B. YEATS 


\title{
THE CORNELL CONCORDANGES
}

\author{
Supervisory Committee \\ M. H. Abrams \\ Ephim G. Fogel \\ William R. Keast \\ James A. Painter, Computer Programmer \\ S. M. Parrish, General Editor
}

POEMS OF MATTHEW ARNOLD

Edited by S. M. Parrish

POEMS OF W. B. YEATS

Edited by S. M. Parrish 
$A$ Concordance to the Poems of

\title{
W. B. YEATS
}

\author{
Edited by \\ STEPHEN MAXFIELD PARRISH
}

Programmed by

JAMES ALLAN PAINTER

\section{Cornell University Press}

ITHACA, NEW YORK 

(C) 1963 by Cornell University

\section{CORNELL UNIVERSITY PRESS}

First published 1963
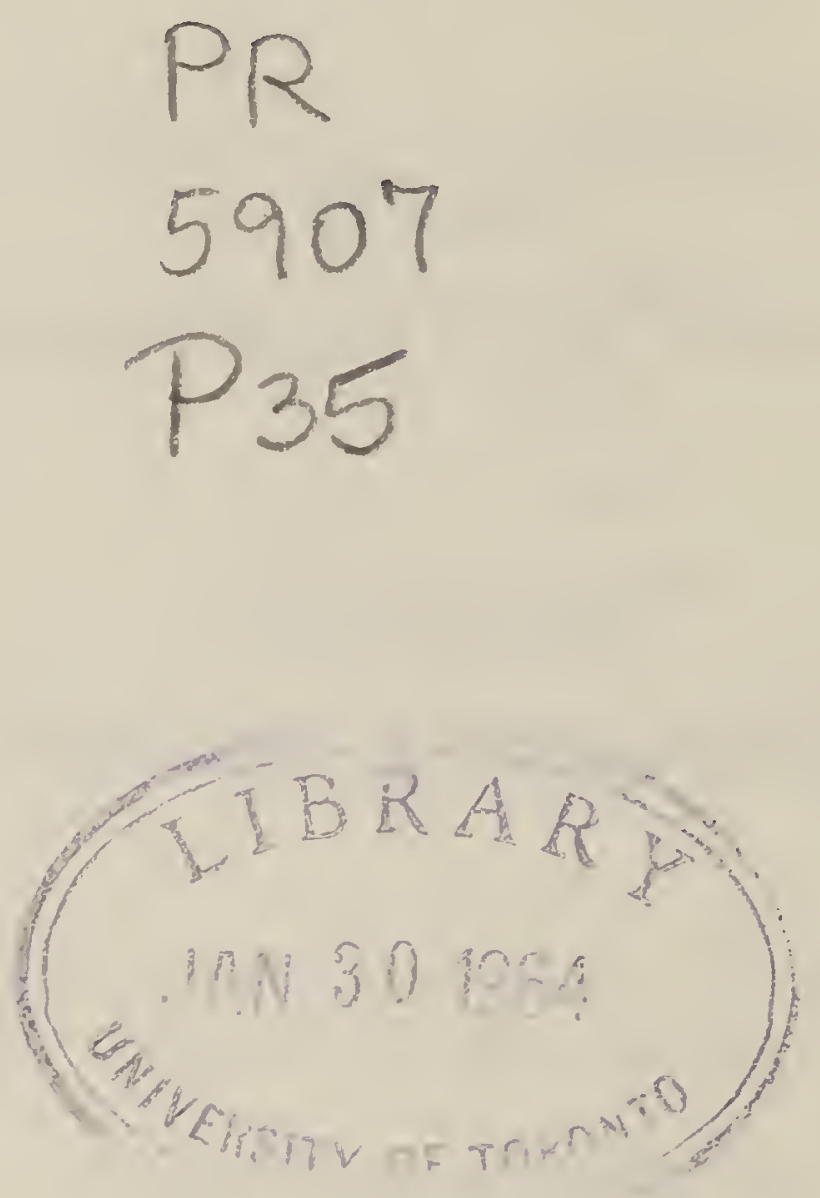

879028

Library of Congress Catalog Card Number: 63-11493

PRINTED IN THE UNITED STATES OF AMERICA 